\title{
Isolation and Characterization of Chitin Nanofibers from Calocybe indica and its Applications
}

\author{
Prakash $P^{1(\mathbb{D})}$, Sowmya $N^{1 \mathbb{D}}$, Sudha $S^{1(\mathbb{D}}$, Masilamani Selvam $M^{1 \mathbb{1}}$, Durgasruthi Pully ${ }^{2 \mathbb{D}}$, \\ Shobana N ${ }^{1}$ (D), Saigeetha $S^{1}$ (i), Antony V Samrot ${ }^{3,}$ * (D) \\ 1 Department of Biotechnology, School of Bio and Chemical Engineering, Sathyabama Institute of Science and Technology, \\ Semmancheri, Chennai - 600119, Tamil Nadu, India \\ 2 Faculty of Science, KU LEUVEN, Belgium - 3000 \\ 3 School of Bioscience, Faculty of Medicine, Bioscience and Nursing, MAHSA University, Bandar Saujana Putra, Selangor \\ - 42610, Malaysia \\ * Correspondence: antonysamrot@gmail.com (A.V.S.); kpprakashmtech@gmail.com (P.P.);
}

Scopus Author ID 36100751800

Received: 11.08.2021; Revised: 20.09.2021; Accepted: 23.09.2021; Published: 31.10.2021

\begin{abstract}
In this study, chitin nanofibers are isolated from Calocybe indica (Milky White Mushroom), and they are further characterized using various analytical techniques such as UV-VIS, FTIR, TGA, Fe - SEM, and XRD. Antioxidant activity of the chitin nanofibers was studied by performing various assays such as DPPH, ABTS, $\mathrm{H}_{2} \mathrm{O}_{5}$ Scavenging Activity, Hydroxyl Radical Activity, Superoxide Assay, and Reduced Glutathione Activity. Isolated Chitin nanofibers were then chemically treated to form hydrogels. The hydrogels formed were further characterized.
\end{abstract}

Keywords: Calocybe indica; chitin nanofibers; antioxidant activity; hydrogels.

(C) 2021 by the authors. This article is an open-access article distributed under the terms and conditions of the Creative Commons Attribution (CC BY) license (https://creativecommons.org/licenses/by/4.0/).

\section{Introduction}

Calocybe indica (milky white mushroom) is a native edible mushroom species that appears white in color and has a firm consistency [1,2]. It belongs to the genus Calocybe and the family Lyophyllaceae. C. india is commercially cultivated in agricultural fields or along the roadside in tropical and subtropical parts of India [3]. The Pileu or the cap of this species measures $10-14 \mathrm{~cm}$ wide and is found to be convex in shape, which further flattens, as the mushroom ages. The stem is generally $10 \mathrm{~cm}$ high with neither the ring nor volva [4]. These can be grown in a warm, humid climate $\left(30 \sim 38{ }^{\circ} \mathrm{C} ; 80 \%\right.$ to $85 \%$ humidity) and hold a longer shelf life without the need for refrigeration. They are less prone to contamination and discoloration when kept under controlled conditions. Additionally, the cost of production of these species is low, suggesting that the industrial production could be a short crop cycle (approx. 7-8 weeks) [3].

Chitin is a fibrous substance generally found in the exoskeletons of shellfish and the cell walls of fungus [5]. Due to the small size of the chitin nanofibers, they show high mechanical and physical properties [6]. The chitin nanofibers extracted from the cell walls of edible mushrooms have more scope as novel functional food [7-9].

Hydrogels are polymer networks that consist of hydrophilic polymer units which tend to swell when added to water $[9,10]$. These can be natural or artificial based on their origin. Chitin hydrogels are naturally originated polymers that have been reported to be non-toxic, 
biocompatible, and biodegradable and hence have potential use in the field of biomedical sciences [11-13].

\section{Materials and Methods}

\subsection{Chemicals used.}

All chemicals used in this study were of analytical grade. Sodium hydroxide $(\mathrm{NaOH})$, hydrochloric acid $(\mathrm{HCl})$, sodium hypochlorite $(\mathrm{NaClO})$, acetic acid $\left(\mathrm{CH}_{3} \mathrm{COOH}\right)$, ethanol $\left(\mathrm{C}_{2} \mathrm{H}_{5} \mathrm{OH}\right)$, calcium chloride dihydrate $\left(\mathrm{CaCl}_{2} .2 \mathrm{H}_{2} \mathrm{O}\right)$, methanol $\left(\mathrm{CH}_{3} \mathrm{OH}\right)$ were bought from SISCON India Pvt Ltd.

\subsection{Collection of milky white mushroom.}

Milky white mushrooms were collected from Mushroom Incubation Center, Center for Ocean Research, Dr. Jeppiaar Research Park, Sathyabama Institute of Science and Technology, Chennai. The mushrooms were washed, dried, and then cut into uniform size.

\subsection{Isolation of chitin nanofibers.}

Extraction of chitin nanofibers from Calocybe indica was carried out as described earlier [6, 14]. Following the chemical treatment, the sample was filtered and washed several times with distilled water to neutralize the residue. The wet fibers were then dispersed in water to obtain $1 \mathrm{wt} \%$ concentration, to which acetic acid was added to adjust the $\mathrm{pH}$ to 3 . The wet fibers were then ultra-sonicated for 1 hour to obtain well-dispersed chitin nanofibers [15]. The nanofiber slurry was further diluted with ethanol and lyophilized to form a sheet of chitin nanofibers.

\subsection{Characterization of chitin nanofibers.}

Chitin nanofibers were characterized to determine the presence of various functional groups, find the changes in the chemical compound after chemical treatment, confirm thermal stability, elucidate its size and surface morphology and find its crystallinity using the techniques such as UV-Visible Spectroscopy, FTIR, TGA, Fe-SEM and XRD.

\subsection{Antioxidant activity of chitin nanofibers.}

The antioxidant property of chitin nanofiber was evaluated using different assays to ensure correlation between different assays and identify antioxidant properties against various substances. DPPH Assay was carried out following the method described earlier [16, 17]. ABTS assay was performed as described earlier [18]. The $\mathrm{IC}_{50}$ value of the sample was calculated, and the percentage inhibition was calculated [19]. Hydrogen peroxide assay was performed with slight modifications [20]. $40 \mathrm{mM} \mathrm{H}_{2} \mathrm{O}_{2}$ was dissolved in $0.1 \mathrm{M} \mathrm{PBS}$ solution. $3.4 \mathrm{~mL}$ of PBS solution was added to each concentration of chitin sample followed by $0.6 \mathrm{~mL}$ of $40 \mathrm{mM} \mathrm{H} \mathrm{O}_{2}$ solution. The absorbance was read at $230 \mathrm{~nm}$. Percentage inhibition was calculated. Hydroxyl radical scavenging activity was performed with the method described earlier with slight modifications [21]. The reaction mixture contained $1 \mathrm{~mL}$ of different concentrations of sample solution; $1 \mathrm{~mL}$ of Iron-EDTA solution, $0.5 \mathrm{~mL}$ of $0.018 \%$ EDTA solution and $0.5 \mathrm{~mL}$ of $0.22 \%$ Ascorbic acid solution. $3 \mathrm{~mL}$ of NASH reagent was added and 
incubated at room temperature for $15 \mathrm{~min}$. The intensity of yellow color developed was read at $412 \mathrm{~nm}$. Further, the Percentage Inhibition was also calculated. Superoxide assay was executed according to the method described earlier with slight modifications [22]. The reaction mixture contained $100 \mu \mathrm{l}$ of different concentrations of the sample, $100 \mu \mathrm{L}$ of $1.5 \mathrm{M}$ NBT, $200 \mu \mathrm{L}$ of $0.1 \mathrm{M}$ EDTA, $50 \mu \mathrm{L}$ of riboflavin, and $2.55 \mathrm{~mL}$ of $0.067 \mathrm{M}$ PBS solution. The reaction tubes were illuminated for 30 minutes. The absorbance was read at $560 \mathrm{~nm}$. Percentage inhibition was calculated.

\subsection{Preparation of hydrogel.}

Calcium solvent was prepared by heating $225 \mathrm{~g}$ of Calcium Chloride dihydrate $\left(\mathrm{CaCl}_{2} \cdot 2 \mathrm{H}_{2} \mathrm{O}\right)$ with $300 \mathrm{~mL}$ of methanol and refluxed at $70^{\circ} \mathrm{C}$ for $4 \mathrm{hr}$ [12]. Chitin nanofiber was then slowly added to the calcium solvent. The suspension was heated at $70^{\circ} \mathrm{C}$ with continuous stirring for $4 \mathrm{hr}$. The chitin solution was obtained and carefully washed with water to prepare a solid gel. , The addition of Chitin solution into an excessive amount of water facilitated the formation of chitin hydrogels [11]. Excess Calcium chloride in the chitin hydrogel was then removed by dialysis against water for 3 days with a change of freshwater 4 times per day.

\section{Results and Discussion}

\subsection{UV-visible spectroscopy.}

Chitin nanofibers exhibited maximum absorbance at 230nm (Figure 1). Dhananasekaran et al. [23] have reported absorbance maxima at $201 \mathrm{~nm}$ for chitin nanoparticles in $0.1 \mathrm{M} \mathrm{HCl}$. Peaks between $300 \mathrm{~nm}$ to $400 \mathrm{~nm}$ might be due to small amounts of impurities.

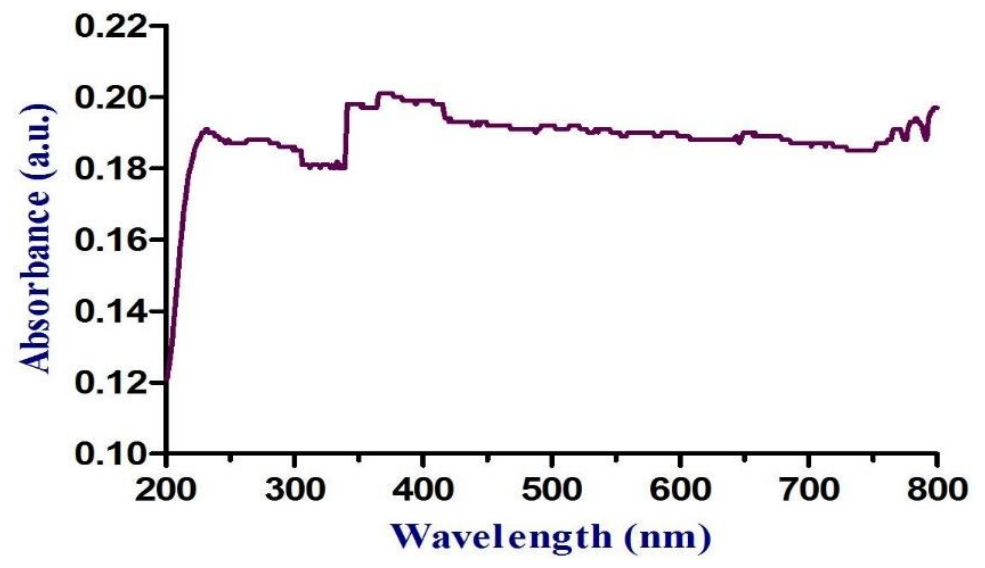

Figure 1. UV- Visible Spectroscopy of Chitin Nanofibers.

\subsection{FT-IR spectroscopy of chitin nanofiber.}

FTIR analysis was carried out in the three regions $\left(500 \mathrm{~cm}^{-1}-1500 \mathrm{~cm}^{-1}, 1500 \mathrm{~cm}^{-1}\right.$ $2500 \mathrm{~cm}^{-1}$ and $2500 \mathrm{~cm}^{-1}-3500 \mathrm{~cm}^{-1}$ ) for the pure chitin nanofibers (Figure 2). Significant troughs were observed at $1655 \mathrm{~cm}^{-1}$ and $1563 \mathrm{~cm}^{-1}$, confirming the presence of amide I and amide II groups, respectively. Ifuku et al. [6] showed similar troughs between $1660 \mathrm{~cm}^{-1}$ and $1620 \mathrm{~cm}^{-1}$ for the amide I group and $1560 \mathrm{~cm}^{-1}$ for the amide II group. Troughs at $2925 \mathrm{~cm}^{-1}$ and $3426 \mathrm{~cm}^{-1}$ are due to the $\mathrm{C}-\mathrm{H}$ stretching and $\mathrm{O}-\mathrm{H}$ stretching, respectively, in chitin. Trung et al. 2015 illustrated IR bands in a similar range. 


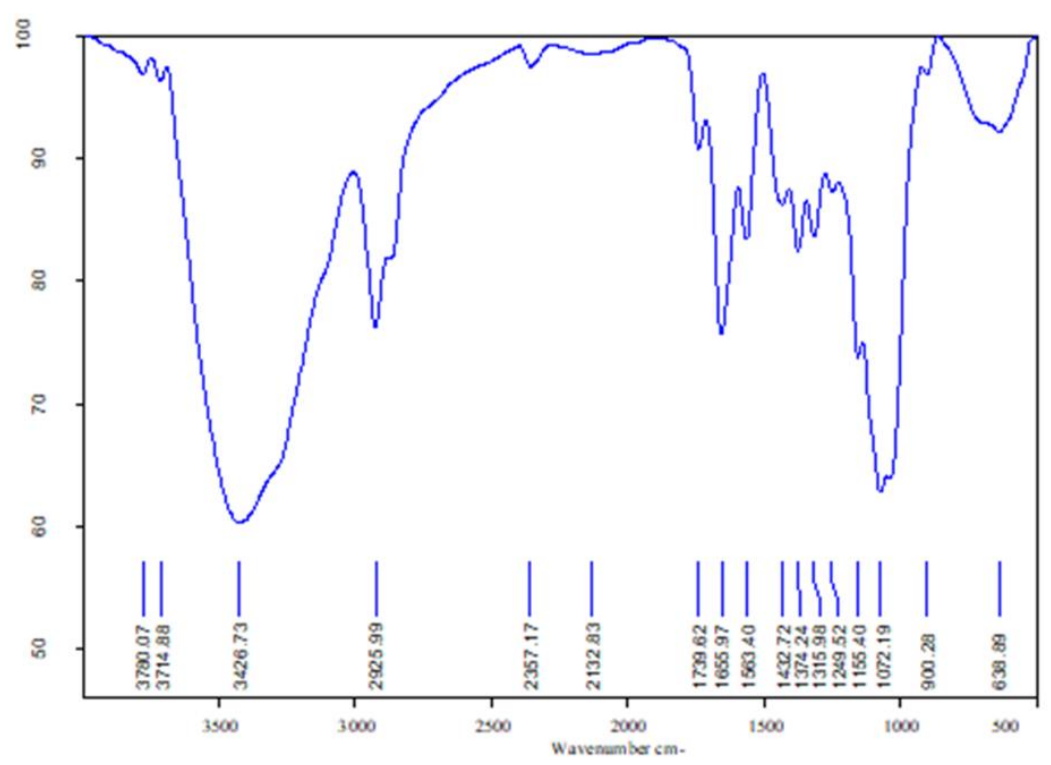

Figure 2. FTIR Spectroscopy of chitin Nanofibers.

\subsection{Thermogravimetric analysis of chitin nanofiber.}

The thermogravimetric analysis of chitin nanofibers was carried out to determine the thermal stability and degradation profile. From the TGA curve (Figure 3), it can be inferred that the nanofiber starts to decompose at $207^{\circ} \mathrm{C}$, characterized by a slight loss of mass. This might be due to the release of moisture content from the sample. Further, a dramatic weight loss is observed between $213^{\circ} \mathrm{C}$ to $402^{\circ} \mathrm{C}$, indicating pyrolysis and decomposition of nanofibers. At $407^{\circ} \mathrm{C}$, the loss in the material is slowed down. It is thus inferred that the chitin nanofiber is being thermostable and further suggests that it can be considered an ideal material for fabrication and drug delivery applications.

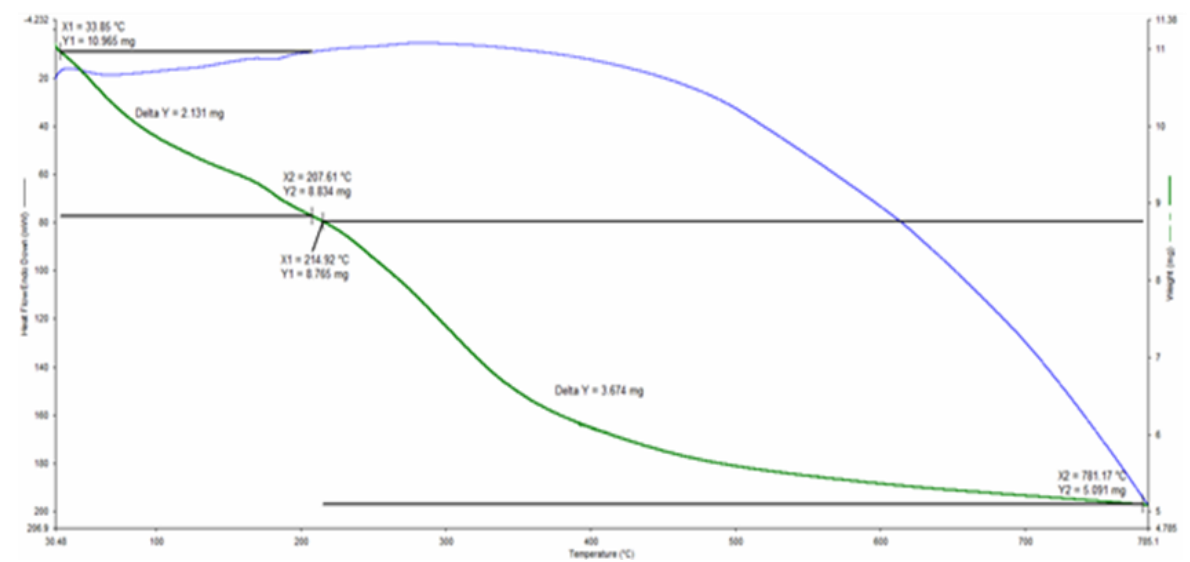

Figure 3. TGA Curve of Chitin Nanofiber.

\subsection{Scanning electron microscopy analysis of chitin nanofiber.}

SEM results showed non-uniformly shaped long and aggregated chitin nanofibers with lengths ranging from $20 \mu \mathrm{m}$ to $100 \mu \mathrm{m}$ (Figure 4). However, Ifuku et al. [6] has reported chitin nanofibers with uniform shape and size on a nanometer scale. 


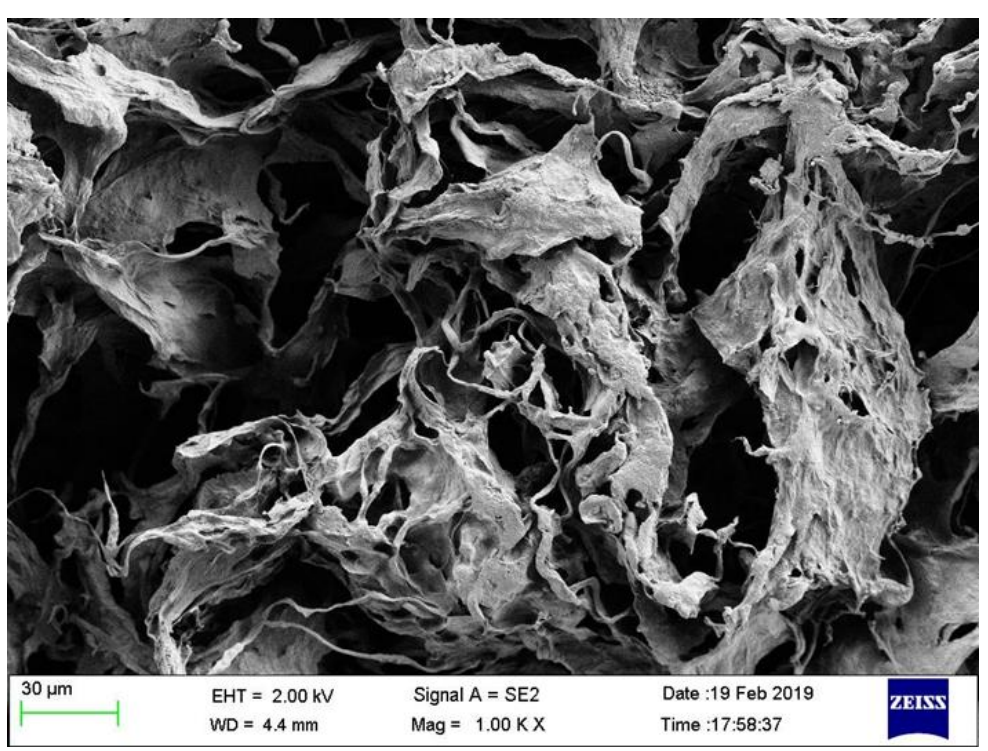

Figure 4. SEM image of Chitin nanofiber.

\subsection{X-ray diffraction crystallography.}

The XRD profile showed sharp peaks at $2 \theta=9.03^{\circ}$ and $18.99^{\circ}$, indicating that the chitin nanofibers are highly crystalline (Figure 5). The peaks confirm a stable $\alpha$ - chitin structure [24].

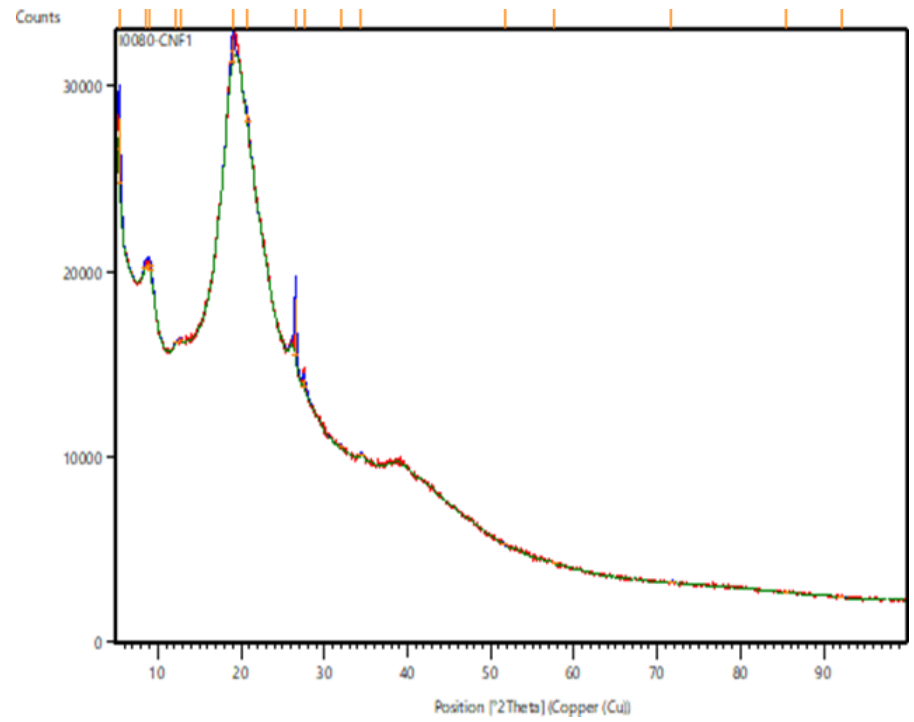

Figure 5. XRD spectra of Chitin Nanofiber.

\subsection{Antioxidant property.}

Antioxidant activity of the chitin nanofibers from Calocybe indica was studied by comparing and correlating the scavenging activity of different assays.

\subsubsection{DPPH assay.}

DPPH assay is a rapid technique for screening the radical scavenging activity of specific compounds. The results showed that the percentage inhibition increased gradually as the concentration increased (Table 1). The $\mathrm{IC}_{50}$ value of the chitin nanofiber sample was found to be at $500 \mu \mathrm{g} / \mathrm{mL}$. The Scavenging activity may be primarily due to the Hydrogen donating ability of the chitin nanofibers [18]. 


\subsubsection{ABTS assay.}

Unlike DPPH assay, the ABTS assay is considerably fast as it involves electron transfer among the molecules. Percentage inhibition of ABTS radical scavenging assay increased more significantly than DPPH assay, and the $\mathrm{IC}_{50}$ value was found to be $3 \mu \mathrm{g} / \mathrm{mL}$ (Table 1), which was less than that obtained by DPPH assay.

\subsection{3. $\mathrm{H}_{2} \mathrm{O}_{2}$ scavenging activity.}

Unlike the DPPH Assay and ABTS assay, $\mathrm{H}_{2} \mathrm{O}_{2}$ scavenging assay did not show any inhibition as the concentration of the sample increased. The major principle behind this assay is the significant decrease in absorbance of $\mathrm{H}_{2} \mathrm{O}_{2}$ as it gets oxidized [20].

\subsubsection{Hydroxyl radical scavenging activity.}

The percentage inhibition pattern of the Hydroxyl scavenging assay was like the ABTS assay. There was a steady increase in the scavenging activity, and the $\mathrm{IC}_{50}$ value was found to be at $30 \mu \mathrm{g} / \mathrm{mL}$ (Table 1$)$.

\subsection{SOD assay.}

Superoxide assay is characterized by the ability of chitin to inhibit the photochemical reduction of NBT [22]. The NBT molecules are reduced to blue formazan [20]. Unlike the other assays, scavenging activity by SOD assay increased gradually and peaked after $100 \mu \mathrm{g} /$ $\mathrm{mL}$ concentration. The $\mathrm{IC}_{50}$ value for the chitin sample was calculated to be $80 \mu \mathrm{g} / \mathrm{mL}$ (Table $1)$.

Table 1. Percentage inhibition of different Antioxidant assays.

\begin{tabular}{c|c|c|c|c|c}
$\begin{array}{c}\text { Concentration }(\boldsymbol{\mu g} / \\
\mathbf{m L})\end{array}$ & $\begin{array}{c}\text { \%Inhibition of } \\
\text { DPPH Assay }\end{array}$ & $\begin{array}{c}\text { \% Inhibition of } \\
\text { ABTS Assay }\end{array}$ & $\begin{array}{c}\text { \% Inhibition of } \\
\mathbf{H}_{2} \mathbf{O}_{2} \text { Assay }\end{array}$ & $\begin{array}{c}\text { \% Inhibition of Hydroxyl } \\
\text { Scavenging Assay }\end{array}$ & $\begin{array}{c}\text { \% Inhibition of SOD } \\
\text { Assay }\end{array}$ \\
\hline 10 & 3.33 & 60.7 & - & 46.9 & 12.50 \\
\hline 30 & 8.33 & 69.8 & - & 50 & 18.75 \\
\hline 100 & 18.33 & 75.8 & - & 53.1 & 68.75 \\
\hline 300 & 43.33 & 86.6 & - & 56.4 & 75.00 \\
\hline 500 & 51.66 & 88 & - & 57.9 & 81.25 \\
\hline 800 & 55.00 & 89 & - & 57.9 & 87.50 \\
\hline 1000 & 60.01 & 91.1 & - & 60.7 & 93.75 \\
\hline
\end{tabular}

3.8. FTIR spectroscopy of chitin hydrogel.

FTIR spectra of Chitin Hydrogel showed a narrow trough at $3414 \mathrm{~cm}^{-1}$ that confirmed the presence of the hydroxyl group (Figure 6). IR bands in the region between $1156 \mathrm{~cm}^{-1}$ and $896 \mathrm{~cm}^{-1}$ correspond to the C-O-C stretching and C-O stretching [25]. Troughs at $1653 \mathrm{~cm}^{-1}$ and $1556 \mathrm{~cm}^{-1}$ represent the presence of amide groups. Tang et al. [26] illustrated IR bands for Chitin/CMC hydrogels at $3446 \mathrm{~cm}^{-1}$ for $\mathrm{OH}$ stretching and bands at $1660 \mathrm{~cm}^{-1}, 1623 \mathrm{~cm}^{-1}$, and $1557 \mathrm{~cm}^{-1}$ for amide groups.

\subsection{Thermogravimetric analysis of chitin hydrogel.}

The TGA curve of hydrogel showed contrasting results from the TGA curve of chitin nanofibers (Figure 7). The hydrogel started to decompose at $95^{\circ} \mathrm{C}$, accompanied by a slight loss in mass due to the release of moisture content. A dramatic weight loss was observed 
between $213^{\circ} \mathrm{C}$ to $402^{\circ} \mathrm{C}$ indicating the decomposition of the hydrogel. The weight loss slowed down at $407^{\circ} \mathrm{C}$. Thus, the results indicate that the hydrogel is thermostable and can be used for fabrication and drug delivery applications.

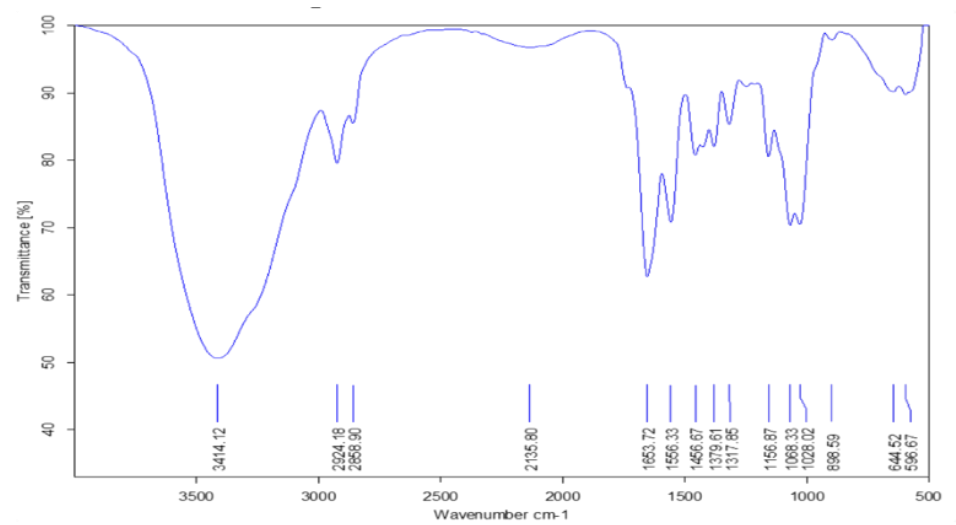

Figure 6. FTIR Spectroscopy of chitin Hydrogel.

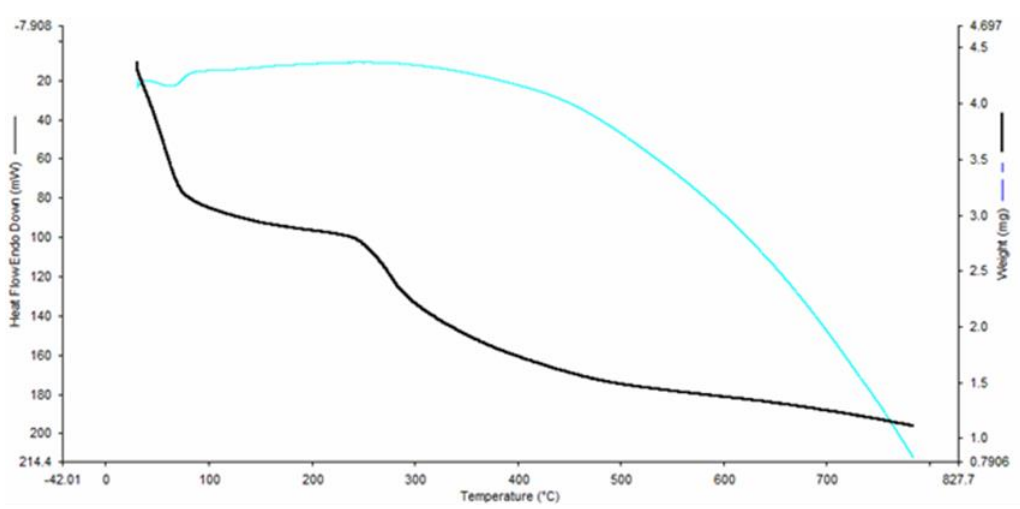

Figure 7. TGA Curve of Chitin Hydrogel.

3.10. Scanning electron microscopy analysis of chitin hydrogel.

SEM image of chitin hydrogels showed a well-connected network of chitin nanofibers with a three-dimensional porous structure (Figure 8). These pores help water molecules to diffuse into the hydrogels. The obtained results were identical to those reported by Tang et al. [26].

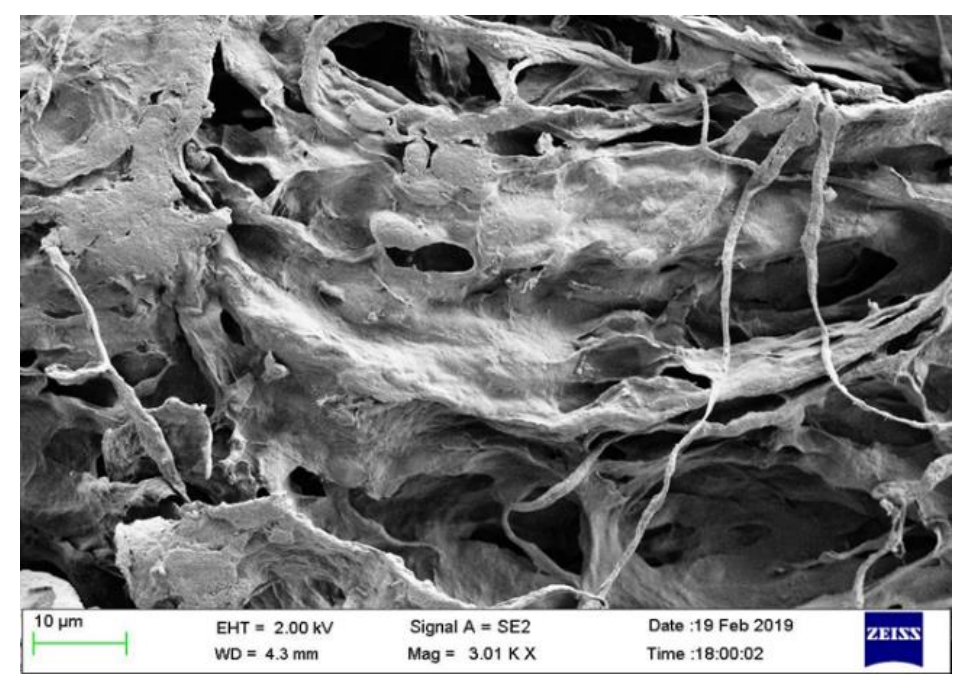

Figure 8. SEM image of chitin Hydrogel. 


\section{Conclusions}

Chitin nanofibers from Calocybe indica were produced and characterized. Various antioxidant assays for the chitin fibers were performed and compared with each other. Chitin hydrogel was prepared from the obtained chitin nanofibers, which were then characterized. The thermal stability of both the chitin nanofibers and the hydrogels was studied. In conclusion, these nanofibers can be used for various biomedical applications.

\section{Funding}

This research received no external funding.

\section{Acknowledgments}

This research has no acknowledgment.

\section{Conflicts of Interest}

The authors declare no conflict of interest.

\section{References}

1. Navathe, S.; Borkar, P.G.; Kadam, J.J. Cultivation of Calocybe indica (P \& C) in Konkan Region of Maharashtra, India. World Journal of Agricultural Research 2014, 2, 187-191, https://doi.org/10.12691/wjar2-4-9.

2. Bekhit, M. Morphological and Molecular Characterization of Milky Mushroom Calocybe indica Mutants. Middle East Journal of Agriculture Research 2016, 05, 739-751.

3. Subbiah, K.A.; Balan, V. A Comprehensive Review of Tropical Milky White Mushroom (Calocybe indica P\&C). Mycobiology 2015, 43, 184-194, https://doi.org/10.5941/MYCO.2015.43.3.184.

4. Purkayastha, R.P.; Chandra, A. New species of edible mushroom from India. Transactions of the British Mycological Society 1974, 62, 415-418, https://doi.org/10.1016/S0007-1536(74)80052-5.

5. Muzzarelli, R.A.A. Chitin nanostructures in living organisms. Chitin, Topics in Geobiology 2011, 34, 1-34, https://doi.org/10.1007/978-90-481-9684-5_1.

6. Ifuku, S.; Nomura, R.; Morimoto, M.; Saimoto, H. Preparation of Chitin Nanofibers from Mushrooms. Materials 2011, 4, 1417-1425, https://doi.org/10.3390/ma4081417.

7. Ifuku, S.; Saimoto, H. Chitin nanofibers: preparations, modifications, and applications. Nanoscale 2012, 4, 3308-3318, https://doi.org/10.1039/c2nr30383c.

8. Dutta, P.; Dutta, J.; Tripathi, V. Chitin and chitosan: Chemistry, properties and applications. J Sci Indus Res 2003, 63, 20-31.

9. Del Valle, L.J.; Díaz, A.; Puiggalí, J. Hydrogels for Biomedical Applications: Cellulose, Chitosan, and Protein/Peptide Derivatives. Gels 2017, 3, https://doi.org/10.3390/gels3030027.

10. Wichterle, O.; LÍM, D. Hydrophilic Gels for Biological Use. Nature 1960, 185, 117-118, https://doi.org/10.1038/185117a0.

11. Chen, C.; Yano, H.; Li, D.; Abe, K. Preparation of high-strength $\alpha$-chitin nanofiber-based hydrogels under mild conditions. Cellulose 2015, 22, 2543-2550, https://doi.org/10.1007/s10570-015-0654-7.

12. Lee, Y.M.; Kim, S.S.; Kim, S.H. Synthesis and properties of poly(ethylene glycol) macromer/ $\beta$-chitosan hydrogels. Journal of Materials Science: Materials in Medicine 1997, 8, 537-541, https://doi.org/10.1023/A:1018594614087.

13. Nata, I.F.; Wang, S.S.-S.; Wu, T.-M.; Lee, C.-K. Carbonaceous hydrogels based on hydrothermal carbonization of glucose with chitin nanofibers. Soft Matter 2012, 8, 3522-3525, https://doi.org/10.1039/C2SM07462A.

14. Ivshina, T.N.; Artamonova, S.D.; Ivshin, V.P.; Sharnina, F.F. Isolation of the chitin-glucan complex from the fruiting bodies of mycothallus. Applied Biochemistry and Microbiology 2009, 45, 313-318, https://doi.org/10.1134/S0003683809030132.

15. Zhao, H.-P.; Feng, X.-Q.; Gao, H. Ultrasonic technique for extracting nanofibers from nature materials. Applied Physics Letters 2007, 90, https://doi.org/10.1063/1.2450666.

16. Fu, H.-Y.; Shieh, D.-E.; Ho, C.-T. Antioxidant And Free Radical Scavenging Activities Of Edible Mushrooms. Journal of Food Lipids 2002, 9, 35-43, https://doi.org/10.1111/j.1745-4522.2002.tb00206.x. 
17. Chen, J.H.; Ho, C.-T. Antioxidant Activities of Caffeic Acid and Its Related Hydroxycinnamic Acid Compounds. Journal of Agricultural and Food Chemistry 1997, 45, 2374-2378, https://doi.org/10.1021/jf970055t.

18. Anraku, M.; Tabuchi, R.; Ifuku, S.; Ishiguro, T.; Iohara, D.; Hirayama, F. Surface-Deacetylated Chitin NanoFiber/Hyaluronic Acid Composites as Potential Antioxidative Compounds for Use in Extended-Release Matrix Tablets. International Journal of Molecular Sciences 2015, 16, 24707-17, https://doi.org/10.3390/ijms161024707.

19. Okoh, S.O.; Asekun, O.T.; Familoni, O.B.; Afolayan, A.J. Antioxidant and Free Radical Scavenging Capacity of Seed and Shell Essential Oils Extracted from Abrus precatorius (L). Antioxidants 2014, 3, 278-287, https://doi.org/10.3390/antiox3020278.

20. Tuba, A.K.; Gülçin, I. Antioxidant and radical scavenging properties of curcumin. Chem Biol Interact 2008, 174, 27-37, https://doi.org/10.1016/j.cbi.2008.05.003.

21. Loganayaki, N.; Siddhuraju, P.; Manian, S. Antioxidant activity and free radical scavenging capacity of phenolic extracts from Helicteres isora L. and Ceiba pentandra L. Journal of Food Science and Technology 2013, 50, 687-695, https://doi.org/10.1007/s13197-011-0389-X.

22. Babu, D.R.; Rao, G.N. Antioxidant properties and electrochemical behavior of cultivated commercial Indian edible mushrooms. Journal of Food Science and Technology 2013, 50, 301-308, https://doi.org/10.1007/s13197-011-0338-8.

23. Dhananasekaran, S.; Palanivel, R.; Pappu, S. Adsorption of Methylene Blue, Bromophenol Blue, and Coomassie Brilliant Blue by $\alpha$-chitin nanoparticles. Journal of Advanced Research 2016, 7, 113-124, https://doi.org/10.1016/j.jare.2015.03.003.

24. Si Trung, T.; Bao, H.N.D. Physicochemical Properties and Antioxidant Activity of Chitin and Chitosan Prepared from Pacific White Shrimp Waste. International Journal of Carbohydrate Chemistry 2015, 2015, https://doi.org/10.1155/2015/706259.

25. Čadež, V.; Šegota, S.; Sondi, I.; Lyons, D.M.; Saha, P.; Saha, N.; Sikirić, M.D. Calcium phosphate and calcium carbonate mineralization of bioinspired hydrogels based on $\beta$-chitin isolated from biomineral of the common cuttlefish (Sepia officinalis, L.). Journal of Polymer Research 2018, 25, https://doi.org/10.1007/s10965-018-1626-Z.

26. Tang, H.; Chen, H.; Duan, B.; Lu, A.; Zhang, L. Swelling behaviors of superabsorbent chitin/ carboxy methyl cellulose hydrogels. J Mater Sci 2014, 49, 2235-2242, https://doi.org/10.1007/s10853-013-7918-0. 